\title{
The complete alk sequences of Rhodococcus erythropolis from Lake Baikal
}

\author{
Alexander Likhoshvay, Anna Lomakina* and Mihail Grachev
}

\begin{abstract}
Background: Rhodococci are bacteria able to degrade a wide range of hydrocarbons, including the alkanes present in crude oil, due to alk genes in their genomes.

Findings: Genome sequencing of DNA from Rhodococcus erythropolis strain 4 (obtained from a deep-water bitumen mound) revealed four alk genes, and the predicted amino acid sequences coded by these genes were highly conserved, having sections up to 11 amino acid residues.

Conclusions: Obtained four genes from Rhodococcus erythropolis were similar to corresponding genes from other bacteria collected from other environments, including marine sources. This indicated a large-scale horizontal alk gene transfer between bacteria from different subgenera.
\end{abstract}

Keywords: Lake Baikal; Natural oil seep; Alkane hydroxylases; Rhodococcus erythropolis

\section{Background}

Alkanes may constitute up to $88 \%$ of the volume present in natural oil, and due to their high toxicity can serve as a convenient source of energy only for oil-degrading microorganisms (van Beilen et al. 2003).

To overcome this obstacle, bacteria have learned to synthesize specific enzymes for extracting energy from $n$ alkanes. The initial step in $n$-alkane oxidation is catalyzed by a monooxygenase complex composed of an alkane hydroxylase $(a l k B)$, rubredoxin reductase $(a l k T)$ and rubredoxin (alkG, an electron carrier), which are known to play an important role in oil bioremediation (Kloos et al. 2006; van Beilen et al. 2003; van van Beilen and Funhoff 2007). Biodegradation starts with cleavage of the $\mathrm{C}-\mathrm{H}$ bond, catalysed by the oxygenase-group enzyme alkane hydroxylase, which inserts an atom of oxygen from $\mathrm{O}_{2}$ into the hydrocarbon molecule. Prior to this catalysis, the enzyme must be activated by NADH (nicotinamide adenine dinucleotide) which transfers a pair of electrons from FAD (flavin adenine dinucleotide) to rubredoxin. One pair of electrons is transferred to alkane hydroxylase leading to the formation of primary or secondary alcohols $\left[\mathrm{R}_{-} \mathrm{CH}_{3}+\right.$ $\left.\mathrm{O}_{2}+\mathrm{NAH}(\mathrm{P}) \mathrm{H}+\mathrm{H}^{+} \rightarrow \mathrm{R}_{-} \mathrm{CH}_{2} \mathrm{OH}+\mathrm{NAD}(\mathrm{P})^{+}+\mathrm{H}_{2} \mathrm{O}\right]$, which

\footnotetext{
* Correspondence: lomakina@lin.irk.ru

Limnological Institute of the Siberian Branch of the Russian Academy of Sciences Ulan-Batorskaya 3, Irkutsk 664033, Russia
}

are further converted to dicarboxylic acids (van Beilen et al. 2003).

This enzyme system was originally discovered in Pseudomonas putida and further research found that the genes encoding for alkane-degrading enzymes (alk-genes, rubredoxin, rubredoxin reductase) are located on a plasmid or chromosomes (van Beilen et al. 2001). Bacteria from different genera, including Rhodococcus, possess similar enzyme systems and alk-genes (Whyte et al. 1998; Whyte et al. 2002). Members of the genus Rhodococcus seem to play significant role in bioremediation of oil spills (Whyte et al. 2002) and are recognized as ideal candidates for the biodegradation of hydrocarbons due to their ability to degrade a wide range of organic compounds (Beard and Page 1998), their hydrophobic cell surface and the production of biosurfactants as well as their ubiquity and robustness in the environment (Larkin et al. 1998; Warhurst and Fewson 1994).

Lake Baikal, the deepest $(1637 \mathrm{~m})$ and oldest $(25 \mathrm{mln}$ y) lacustrine reservoir on Earth, is located in the middle of Eurasia. During a 2008 exploration using Mir submersibles, natural oil seepages surrounded with "bitumen mounds" were discovered on the lake bottom (Khlystov et al. 2009). These structures are stable, inhabited by living creatures and persist even if the source of oil is depleted. One of these bitumen mounds (No. 8) contained $148 \mathrm{mg} / \mathrm{g}$ of aliphatic $\mathrm{C}_{22}-\mathrm{C}_{34} n$-alkanes (primarily $\mathrm{C}_{25}$ ) where several 
strains of bacteria were isolated and later identified as Rhodococcus erythropolis (Likhoshvay et al. 2013) by means of $16 \mathrm{~S}$ rRNA analysis.

This study aimed to identify alk genes in the genome of one of these isolates (strain 4) by nucleotide and complete genome sequence analysis. Strain 4, identified as R. erythropolis, has four alk-genes which differed from each other, but were similar to corresponding genes in bacteria from other habitats.

\section{Materials and methods}

\section{Bacterial strain}

R. erythropolis strain 4 (Acc. No HQ702471), isolated from bitumen mound 8 at the natural oil seep near Cape of Gorevoi Utes (10 km offshore, depth $900 \mathrm{~m}$, Central Baikal) (Likhoshvay et al. 2013).

\section{DNA extraction and sequencing analysis}

DNA was extracted by the method of Sambrook et al. (1989) with minor modifications - enzymatic lysis followed by phenol-chloroform extraction.

Complete genome sequencing of DNA was carried out according to the manual/protocol provided with the Illumina GAIIx (India). Number of readings equalled to approximately $10 \mathrm{Mbp}$. Reassembling of individual nucleotide sequences by Velvet_1.1.02 resulted to 3897 contigs with an average length of $1.8 \mathrm{Kbp}$ and a total length of $6.9 \mathrm{Mbp}$. The nucleotide sequences of the alkB genes were translated into amino acid sequences by the Expasy Translate Tool (http://web.expasy.org/tools/translate/) and uploaded to the NCBI data base with the following accession numbers: alkane hydroxylase 1 (KF498365), alkane hydroxylase 2 (KF498366), alkane hydroxylase 3 (KF498367), alkane hydroxylase 4 (KF498368).

Homology between the four sequences was estimated by BLASTX (http://blast.st-va.ncbi.nlm.nih.gov/Blast.cgi) where the nucleotide sequences and inferred amino acid sequences were aligned with homologous sequences retrieved from GenBank using the CLUSTAL W software. A phylogenetic tree for the genes was constructed by the neighbor-joining method (Saitou and Nei 1987) using the MEGA4 program (Tamura et al. 2007). The relative synonymous codon usage (RSCU) was computed for the alkB genes and correspondence analysis was performed using CODONW software.

\section{Results}

Examination of the complete genome DNA sequence of $R$. erythropolis strain 4 (isolated from the inner part of a bitumen mound) revealed four alk genes: alk1 was 386, alk2 was 389, alk3 was 408 and alk4 was 400 amino acids in length. All four sequences for these alkane hydroxylases had homologous, synonymous and significant substitutions (Figure 1). The highly conserved sequences, typical of amino acid sequences (HE[L/M]xHK, EHxxGHH, LQRH[S/A]DHHA) from alkane-degrading bacteria (van Beilen et al. 2005), were found to have the following sequences - HELGHK, EHNxGHH and LQRHSDHHA. According to data obtained by phylogenetic analysis (Figure 2), the alkane hydroxylases were located on four different branches of the tree with corresponding sequences from other rhodococci.

Complete amino acid sequences obtained from $R$. erythropolis strain 4 were compared to the recently published genome (NCBI) of R. erythropolis PR4 (Sekine et al. 2006) (Figure 3) and found to be nearly identical: alkane hydroxylase 1-9 substitutions including 6 synonymous (97.6\% identity); alkane hydroxylase 2-1 nonsynonymous substitution (99.7\% identity); alkane hydroxylase 3-5 substitutions including 4 synonymous ( $98.7 \%$ identity); alkane hydroxylase 4-2 synonymous, 3 nonsynonymous substitutions and 5 inserts of $2-3$ amino acids ( $94.2 \%$ identity).

Comparative analysis of a wide range of homologous eubacterial sequences (NCBI) revealed that the genome of $R$. erythropolis strain 4 contained highly conserved areas. In the sequence of the fourth alkane hydroxylase (BAH36166) EHNFGHH - polar histidine $(\mathrm{H})$ with basic properties was substituted for a nonpolar hydrophobic phenylalanine $(\mathrm{F})$. The same substitutions were only found in corresponding sequences of $R$. erythropolis SK121 (ZP04385381) and R. erythropolis PR4 (YP002768905).

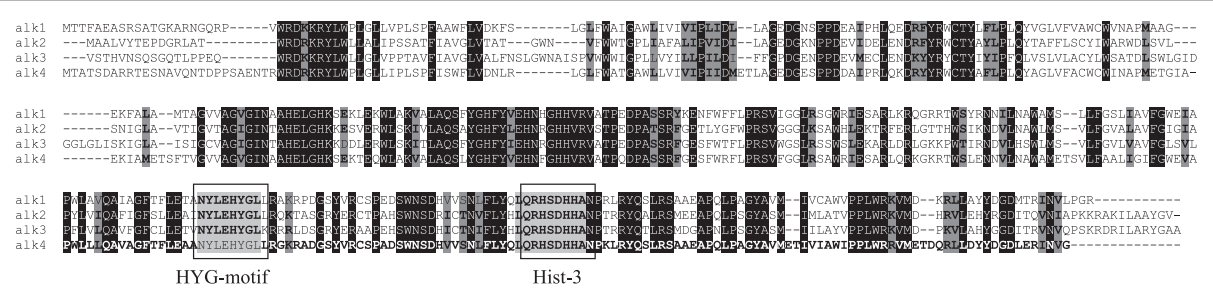

Figure 1 Alignment of the amino acid sequences corresponding to the Rhodococcus erythrypolis strain 4. One conserved His boxes (Hist-3) and the additional HYG motif are boxed and shaded gray. Amino acid residues, conserved in all alkane hydroxylases, are in black colour. The degree of conservation at each position was created using Clustal X. 


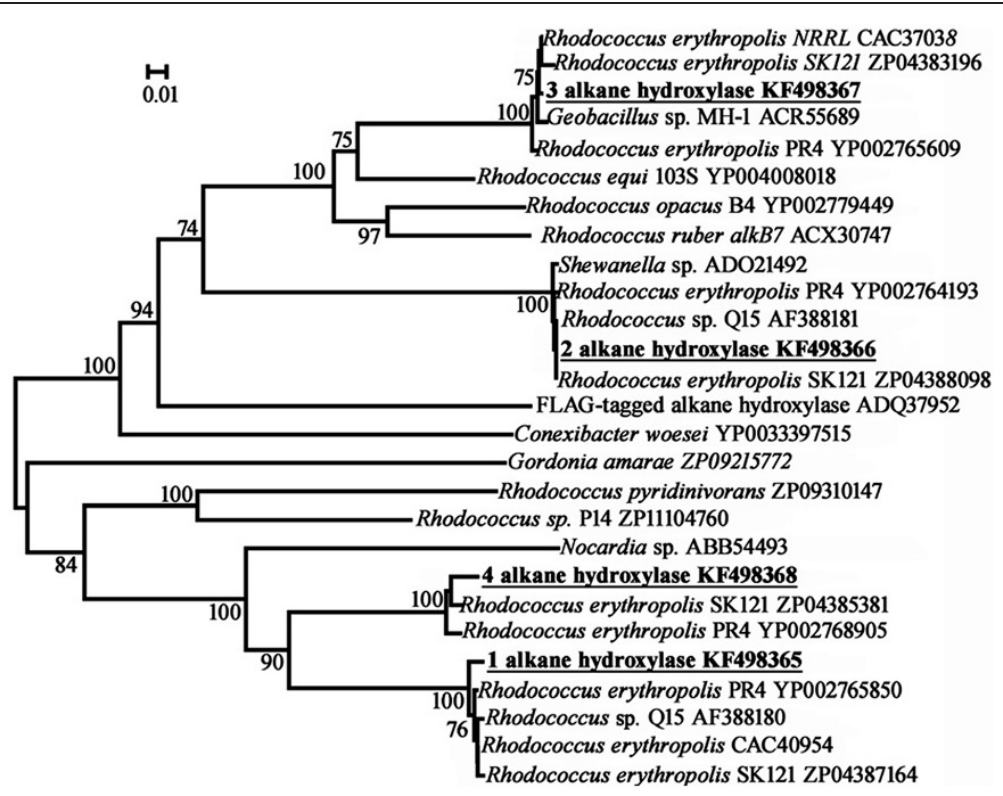

Figure 2 Phylogenetic tree based on amino acid sequence alignment for alkB genes from R. erythropolis strain 4 (in bold). Scale bar, 0.01 substitutions per amino acid site. Numerals indicate the statistical reliability of the branching order as determined by bootstrap analysis of 100 alternative trees. Values exceeding $70 \%$ were considered significant.

\section{Discussion}

$A l k B$ genes in the genomes of Gram-positive and Gramnegative alkane-degrading bacteria are usually present as several individual copies (van Beilen et al. 2003). In particular, $R$. erythropolis NRRL B-16531 and $R$. erythropolis Q15 possess four alkB homologues and suggests these bacteria tend to have several alkB-genes encoding for alkane hydroxylase (Whyte et al. 2002). In the genome of the $R$. erythropolis strain 4, 4 nucleotide sequences for (oxygenase group) alkane hydroxylases were identified. A 5th alkB gene has also been identified which encoded for rubredoxin reductase, but did not cluster the other 4 and will be discussed in later articles.
The alkane hydroxylase amino acid sequence homologies between $R$. erythropolis strain 4, R. erythropolis SK121 and R. erythropolis PR4 are remarkable for the following reasons: strain SK121 (Hamamura et al. 2008) was isolated from oil contaminated soil and tends to utilise aromatic hydrocarbons. Strain PR4 was isolated at a depth of $1 \mathrm{~km}$ from the Pacific Ocean and is unable to utilise arenes, but does use $n$-alkanes with chain length of $\mathrm{C}_{8}-\mathrm{C}_{20}$ as the sole energy source (Sekine et al. 2006). The $R$. erythropolis strain 4 was isolated from the inner part of bitumen mound, located on the bottom of Lake Baikal and tends to utilise $n$-alkanes with a broader chain length $\left(\mathrm{C}_{12}-\mathrm{C}_{29}\right)$. This adaptation could be explained by

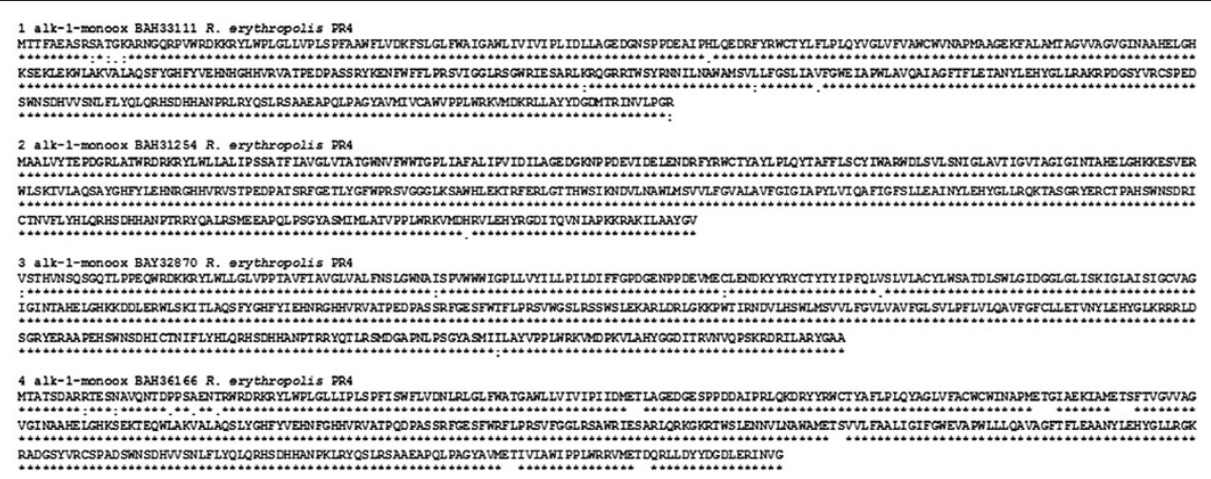

Figure 3 Amino acid sequence alignment of the four new alkane hydroxylases from $R$. erythropolis strain 4 from Lake Baikal with another strain already in the literature (R. erythropolis PR4). Conserved regions (*), synonymous substitutions (:), significant substitutions (·) and unspecified substitutions $\left(\_\right.$). 
the composition of the bitumen mound 8 , which included $n$-alkanes with chain lengths of $\mathrm{C}_{22}-\mathrm{C}_{34}$ (Likhoshvay et al. 2013). However, as a final product of alkanes biodegradation serve fatty acids with chain length of $\mathrm{C}_{16}-\mathrm{C}_{18}$. These substances could further be degraded during phospholipid synthesis (Alvarez 2010).

Homologue sequence analysis (NCBI) of the 4 amino acid sequences from $R$. erythropolis strain 4 revealed that the 4 alkane hydroxylases were highly divergent, however each enzyme was similar to the corresponding homologue from Rhodococcus. The absence of other bacterial genera in the analyses suggested this was an enzyme system specific to rhodococci, based on the differences in alkane hydroxylases.

All alkane-degrading bacteria have alkane hydroxylases containing the following three sequences: (numbering from Pseudomonas putida GPo1): $\mathrm{H}_{138} \mathrm{E}[\mathrm{L} / \mathrm{M}] \times \mathrm{xHK}_{143}$, $\mathrm{E}_{167} \mathrm{HxxGHH}_{173}$ and $\mathrm{L}_{309} \mathrm{QRH}[\mathrm{S} / \mathrm{A}] \mathrm{DHHA}_{317}$. According to van Beilen et al. (2005), a histidine in the second and third sequences may affect enzyme activity. Furthermore, the histidine residues in these conserved sequences bind two atoms of $\mathrm{Fe}(\mathrm{II})$ in the alkane hydroxylase (Whyte et al. 1999; van Beilen et al. 2005). The longest sequence, $\mathrm{L}_{309} \mathrm{QRH}[\mathrm{S} / \mathrm{A}] \mathrm{DHHA}_{317}$, was present in the alkane hydroxylase sequences of most hydrocarbon-oxidising bacteria, including $R$. opacus $\mathrm{B} 4$, which was initially isolated from oil contaminated soil and metabolized a wide range of arenes and aliphatics. The genes coding for these enzymes were located in (at least) six replicons: a large linear chromosome of 7,913,450 bp, two linear plasmids pROB01 (558,192 bp) and pROB02 (244,997 bp), and three circular ones - pKNR (111,160 bp), pKNR01 (4,367 bp) pKNR02 (2,773 bp). Originally isolated at a depth of $1 \mathrm{~km}$ in Pacific Ocean, R. erythrypolis PR4 had a circular chromosome of $6,516,310 \mathrm{bp}$, a separate linear plasmid - pREL1: 271,577 bp and two circular plasmids pREC1 - 104,014 bp and pREC2 - 3,637 bp. The first two code for most of the genes responsible for alkane metabolism. Obviously, plasmid alk genes could be transferred between bacteria by horizontal gene transfer (Turova et al. 2008). Hence, bacteria of the Geobacillus genus could obtain alk genes from Rhodococcus.

The least ones could be found everywhere and in different climatic zones and they have enormous biodegradation potential to utilise widest range of organic substrates. The structure of alk genes apparently has an adaptive character and encodes alkane hydroxylase. This might be necessary for $R$. erythropolis strain 4 to degrade of heavy $n$-alkanes, which are present in bitumen mound 8 at low temperture $\left(3.5^{\circ} \mathrm{C}\right)$ and high pressure (90 atm).

\section{Competing interests}

The authors declare that they have no competing interests.

\section{Authors' contributions}

AL wrote most of the text and lot of analytical work in the lab and the literature study, MG edited the manuscript and supervised the entire study, $\mathrm{AL}$ corrected the manuscript and took care about revised the manuscript. All authors read and approved the final manuscript.

\section{Acknowledgements}

We would like to thank Genotypic (Bangolore, India) and Dr. Roja C. Mugasimangalam personally for assistance in sequencing on the Illumina GAllx; Dr. T.A. Scherbakova for consulting assistance and Dr. Y.P. Galachyants for assembling the contigs. The work was supported by grants from Integration Project SB RAS 82 and Programme of RAS Presidium 23.8.

Received: 13 February 2014 Accepted: 9 October 2014 Published: 21 October 2014

\section{References}

Alvarez HM (2010) Biology of Rhodococcus. Springer, London, New York Beard TM, Page MI (1998) Enantioselective biotransformations using rhodococci. Antonie Leeuwenhoek 74:99-106

Hamamura N, Fukui M, Ward DM, Inskeep WP (2008) Assessing soil microbial populations responding to crude-oil amendment at different temperatures using phylogenetic, functional gene (alkB) and physiological analyses. Environ Sci Technol 42(20):7580-7586

Khlystov OM, Zemskaya TI, Sitnikova TYA, Mekhanikova IV, Kaigorodova IA, Gorshkov AG, Timoshkin OA, Shubenkova OV, Chernitsyna SM, Lomakina AV, Likhoshvai AV, Sagalevich AM, Moskvin VI, Peresypkin VI, Belyaev NA, Slipenchuk MV, Tulokhonov AK, Grachev MA (2009) Bottom bituminous constructions and biota inhabiting them according to investigation of Lake Baikal with the Mir submersible. Dokl Earth Sci 429(8):1333-1336

Kloos K, Munch JC, Schloter M (2006) A new method for the detection of alkanemonooxygenase homologous genes $(a / k B)$ in soils based on PCRhybridization. J Microbiol Methods 66:486-496

Larkin MJ, De Mot R, Kulakov LA, Nagy I (1998) Applied aspects of Rhodococcus genetics. Antonie Leeuwenhoek 74:133-153

Likhoshvay A, Khanaeva T, Gorshkov A, Zemskaya T, Grachev M (2013) Do oil-degrading Rhodococci contribute to the genesis of deep water bitumen mounds in Lake Baikal? Geomicrobiol 30(3):209-213

Saitou N, Nei M (1987) The neighbor-joining methods: a new method for reconstructing phylogenetic trees. Mol Biol Evol 4:406-425

Sambrook J, First EF, Maniatis T (1989) Molecular Cloning. A Laboratory Manual Cold. Spring Harbor Laboratory Press, New York

Sekine M, Tanikawa S, Omata S, Saito M, Fujisawa T, Tsukatani N, Tajima T, Sekigawa T, Kosugi H, Matsuo Y, Nishiko R, Imamura K, Ito M, Narita H, Tago S, Fujita N, Harayama S (2006) Sequence analysis of three plasmids harboured in Rhodococcus erythropolis strain PR4. Environ Microbiol 8(2):334-346

Tamura K, Dudley J, Nei M, Kumar S (2007) MEGA4: molecular evolutionary genetics analysis (MEGA) software version 4.0. Mol Biol Evol 24:1596-1599

Turova TP, Nazina TN, Mikhailova EM, Rodionova TA, Ekimov AN, Mashukova AV, Poltaraus AB (2008) AlkB Homologues in thermophilic bacteria of the genus Geobacillus. Mol Boil 42(2):247-257

van Beilen JB, Funhoff EG (2007) Alkane hydroxylase homologues involved in microbial alkane degradation. Appl Microbiol Biotechnol 1:13-21

van Beilen JB, Panke S, Lucchini S, Franchini AG, Röthlisberger M, Witholt B (2001) Analysis of Pseudomonas putida alkane degradation gene clusters and flanking insertion sequences: Evolution and regulation of the alk-genes. Microbiol 147:1621-1630

van Beilen JB, Li Z, Duetz WA, Smits THM, Witholt B (2003) Diversity of alkane hydroxylase systems in the environment. Oil Gas Scien Technol 58(4):427-440

van Beilen JB, Smits THM, Roos FF, Brunner T, Balada SB, Rothlisberger M, Witholt $B$ (2005) Identification of an amino acid position that determines the substrate range of integral membrane alkane hydroxylases. J Bacteriol 187(1):85-91

Warhurst AW, Fewson CA (1994) Biotransformations catalyzed by the genus Rhodococcus. Crit Rev Biotechnol 14:29-73

Whyte LG, Hawari J, Zhou E, Bourbonnière L, Inniss WE, Greer CW (1998) Biodegradation of variable-chain-length alkanes at low temperatures by a psychrotrophic Rhodococcus sp. Appl Environ Microbiol 64:2578-2584

Whyte LG, Slagman SJ, Pietrantonio F, Bourbonnière L, Koval SF, Lawrence JR, Inniss WE, Greer CW (1999) Physiological adaptations involved in alkane 
